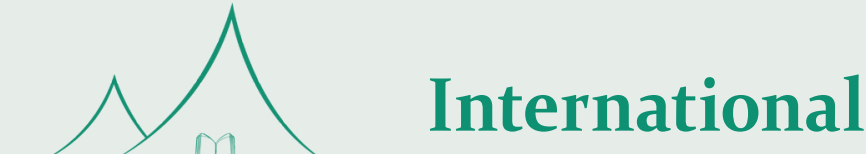 \\ madridge Journal of Material Science and Research \\ Interconnecting Scientific World
}

Research Article

Open Access

\section{Extrusion Foaming of High Impact Polystyrene: Effects of Processing Parameters and Materials Composition}

\author{
Emre Demirtaş ${ }^{1,2}$, Hakan Özkan ${ }^{1,2}$ and Mohammadreza Nofar ${ }^{1 \star}$ \\ ${ }^{\prime}$ Department of Metallurgical and Materials Engineering, Chemical and Metallurgical Engineering Faculty, Istanbul Technical University, \\ Maslak, 34469 Istanbul, Turkey \\ ${ }^{2}$ Arcelik A.S. Central RED Department, Materials Technologies, Tuzla 34950 Istanbul, Turkey
}

\section{Article Info \\ *Corresponding author: Mohammadreza Nofar \\ Department of Metallurgical \& Materials Engineering \\ Faculty of Chemical and Metallurgical Engineering \\ Istanbul Technical University \\ Maslak/Istanbul, 34469 \\ Turkey \\ E-mail: nofar@itu.edu.tr}

Received: March 29, 2018

Accepted: April 9, 2018

Published: April 16, 2018

Citation: Demirtaş E, Özkan H, Nofar M. Extrusion Foaming of High Impact Polystyrene: Effects of Processing Parameters and Materials Composition. Int J Mater Sci Res. 2018; 1(1): 9-15.

doi: 10.18689/ijmsr-1000102

Copyright: @ 2018 The Author(s). This work is licensed under a Creative Commons Attribution 4.0 International License, which permits unrestricted use, distribution, and reproduction in any medium, provided the original work is properly cited.

Published by Madridge Publishers

\begin{abstract}
This study investigates the extrusion foaming behavior of high impact polystyrene (HIPS) through a twin-screw extruder using two various types of chemical blowing agents (CBA). The die temperature profile was firstly tailored during the foaming of HIPS for two different CBAs. Then the CBA content effect on the foaming behavior of HIPS was verified for both CBAs. The effect of screw speed (RPM) on the foaming behavior of HIPS was, subsequently, illustrated for both CBAs. It was found that the cell density and the void fraction of the HIPS foamed samples increased at the maximum CBA content of $5 \mathrm{wt} \%$ and the minimum screw RPM of 100 . The HIPS extrusion foaming behavior was further investigated via blending it with general purpose PS (GPPS) at the blending ratios (wt\%/wt\%) of 75/25 and 50/50, as well as, via compounding HIPS with three different inorganic fillers (i.e., micro-lamellar talc, talc, and calcium carbonate) at three different contents (i.e., 1, 2, and $3 \mathrm{wt} \%$ ). The increase in GPPS and inorganic filler contents increased the cell density and void fraction of HIPS foams while the inorganic filler type did not reveal much differences in the foaming results.
\end{abstract}

Keywords: HIPS; Extrusion; Foaming; Chemical Blowing Agent.

\section{Introduction}

Polystyrene (PS) is an amorphous thermoplastic with a glass transition temperature around $100^{\circ} \mathrm{C}$ and is widely being used in commodity applications due to its low-cost and reasonable physical and mechanical properties [1]. Among the PS products, the use of PS foams is also of a great interest in variety of commodity applications, such as packaging, cushioning, construction, and food application. This is due to the reduced weight and cost benefit of the foamed samples while not high mechanical properties are expected in most of the noted applications. PS foams are currently being manufactured in various structures such as extruded PS sheets (XPS), expanded bead foams (EPS), and three-dimensional complex geometries via such manufacturing technologies as extrusion foaming, bead foaming, and foam injection molding, respectively [2].

Extrusion foaming is widely being used in manufacturing continuous simple twodimensional profiles through which various foam densities could be obtained. The foam morphology in extrusion foaming could be controlled via controlling several parameters such as die temperature profile [3-4], die geometry (i.e., L/D ratio) [5-10], die pressure and pressure drop rate [12-17], melt rheological properties [18-26], crystallization kinetics [27- 
30] of the polymer/gas mixture, and the type and content of blowing agents [31-34]. Among the blowing agents, despite their high solubility in polymer melts, the use of hydro-fluorocarbons(HFCs), hydro-chloro-fluoro-carbon (HCFCs) and hydrocarbons is banned due to their toxic and flammable features [35-38]. Therefore, the attempts are being made to use green blowing agents such as gas and supercritical $\mathrm{CO}_{2}$ and $\mathrm{N}_{2}$ in manufacturing of plastic foams [39]. Among these, however, $\mathrm{CO}_{2}$ reveals high solubility than $\mathrm{N}_{2}$ which causes the achievement of lower density foams when using $\mathrm{CO}_{2}$ [40-42]. On the other hand, $\mathrm{N}_{2}$ possesses higher cell nucleation power due to its high diffusivity [43]. During the extrusion foaming, the decrease in barrel temperature increases the solubility of the $\mathrm{CO}_{2}$ inside the polymer melts whereas the solubility of $\mathrm{N}_{2}$ increase with barrel temperature increase [44-47]. In this context, to manufacture continuous foam products, the use of $\mathrm{CO}_{2}$ or $\mathrm{N}_{2}$ as physical blowing agents (PBAs) are highly preferred than chemical blowing agents (CBAs) due to the achievements of foams with more uniform structure and the lower cost of the blowing agents [48]. On the other hand, CBAs do not require much of side accessories and equipment such as a continuous syringe pump and extruder modifications required when using PBAs. Therefore, a lot of industries might be interested in using CBAs in order to avoid the modification of their production line.

When the polymer melts along the extruder, with the addition of CBA or injecting the PBA into the melt, polymer/gas mixture starts to be generated under higher pressure and the mixture will be flowing along the extruder. However, the generated pressure must stay beyond the solubility limit of polymer/gas in order to avoid having undissolved gas within the melt along the extruder [49-50]. The die pressure and the pressure drop rate could be controlled by the die temperature, die geometry, and melt viscosity of the polymer/gas mixture. The sudden pressure drop at the die nozzle creates thermodynamic instability and causes cell nucleation and growth during the foaming step [51-52]. When the die temperature is too high, the die pressure drops and the gas loss through the hot skin layer of the polymer foam is more likely. Due to the increased gas loss and the low melt strength of the polymer, the cell coalescence would also be more probable. On the other hand, if the die temperature is too low, the polymer melt becomes too stiff to be expanded although the cell nucleation could be promoted with the increased die pressure and pressure drop rate.

Moreover, in order to improve the cell nucleation and to control the growth, and hence the final foams properties, inorganic fillers could be used as cell nucleating agents during foaming. The stress variations around the rigid fillers will generate pressure variation which causes heterogeneous cell nucleation around these solid particles. In the case of low melt strength polymers, the existence of these fillers could also improve the melt strength during the foaming and thereby the cell coalescence could be hindered while more expansion could be obtained.

In 1993, Park et al. [53-54] illustrated the microcellular foaming of HIPS through extrusion foaming using $\mathrm{CO}_{2}$ as physical blowing agent. They showed that the cell size reduction is highly dependent on the pressure drop rate and the L/D ratio of the filamentary die. They also observed that increasing the die pressure and the melt strength by lowering the die temperature profile profoundly increases the cell nucleation. Park et al. [55-56] also showed that the increase in $\mathrm{CO}_{2}$ content increases the cell density of HIPS foams. This was also shown by Shimbo et al.during the extrusion foaming of PS when using $\mathrm{CO}_{2}$ as the physical blowing agent [57].

In this study, we investigated how the processing parameters and materials modification influence the extrusion foaming behavior of HIPS when using chemical blowing agent. Moreover, the variations of foam morphology were explored when using HIPS blends with GPPS and composites by adding inorganic fillers.

\section{Experimental}

\section{Materials}

HIPS was supplied from Versalis SPA. This HIPS shows the environmental stress cracking resistant (ESCR) behavior. General Purpose PS(GPPS) was also supplied from Dow Chemicals. The melt flow indext (MFI) of HIPS and GPPS were measured as $3.5 \mathrm{~g} / 10 \mathrm{~min}$ and $4.5 \mathrm{~g} / 10 \mathrm{~min}$, respectively. The specific gravity (Mettler A1201 density measurement device) of HIPS and GPPS are also $1.04 \mathrm{~g} / \mathrm{cm}^{3}$ and $1.05 \mathrm{~g} / \mathrm{cm}^{3}$ respectively. The $\mathrm{CO}_{2}$ based endothermic chemical blowing agents (CBA) used in these experiments were also Hydrocerol products produced by Clariant Inc. Two different grades of Hydrocerol that have different decomposition temperatures are named as CBA 1 and 2. Both CBAs were used at the contents of 1, 3 and $5 w t \%$. Figure 1 shows the DSC and TGA curves of these chemical blowing agents, respectively. In HIPS composites, the used inorganic fillers as cell nucleating agents were calcium carbonate (Omya 5-Gz), five micro-sized talc (Omya) and one micro-sized micro-lamellar talc (Imerys). In HIPS blends and composites foamingexperiments, $5 \%$ wt. of CBA was used.
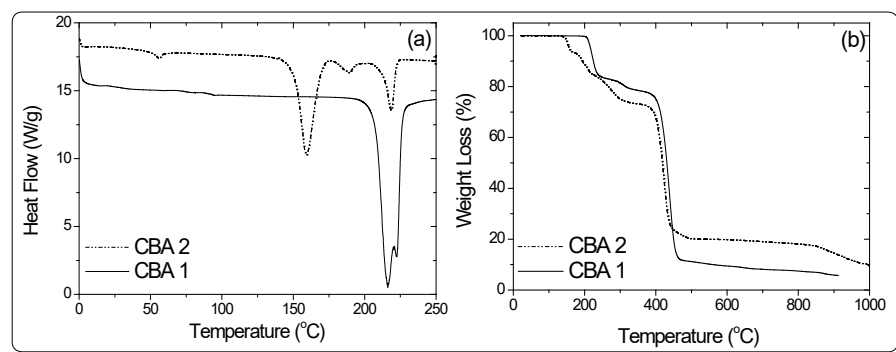

Figure 1. DSC Heating thermograms (a) and TGA curves (b) of the CBAs used during the foaming

\section{Experimental Setup and Procedure}

Foaming was conducted in a twin screw extruder (PRISM TSE-24-HC) having an L/D ratio of 26 at a processing temperature range of $200-230^{\circ} \mathrm{C}$. The filamentary die having, respectively, 2 $\mathrm{mm}$ diameter and $4 \mathrm{~mm}$ length was used in order to produce foamed filaments. Five different die temperatures were set as $130,150,160,170$, and $180^{\circ} \mathrm{C}$. After determination of the most proper die temperature, the CBA type and content (i.e., 1,3 and 5 \%wt.) were investigated. The RPM effect (i.e., 100, 150, 200 
and $250 \mathrm{rpm}$ ) on the foaming behavior of HIPS was explored using both CBA 1 and CBA 2. In order to investigate the HIPS extrusion foaming behavior via blending with GPPS, the HIPS/ GPPA blends were foamed at the blending weight ratios of $75 \mathrm{w} / 25 \mathrm{w}$ and $50 \mathrm{w} / 50 \mathrm{w}$. Moreover, the HIPS foaming behavior was analyzed via compounding HIPS with three different inorganic fillers (i.e., microlamellar talc, talc, and calcium carbonate) at three different contents (i.e., 1, 2, and 3 wt \%). CBA 1 at the ratio of $5 \mathrm{wt} \%$ was fixed for all foaming experiments of blends and composites. The die temperature and the screw RPM were also fixed at $150^{\circ} \mathrm{C}$ and 100 , respectively.

\section{Foam characterization}

The foams' densities were measured according to Archimedes principle using Mettler A1201 density measurement device based on ASTM D792-00. Void fraction values were then calculated using Equation 1. Cell density and cell distributions of samples were observed using ZEISS scanning electron microscopy (SEM). The cell density of samples was measured using Equation 2.

$$
\begin{array}{ll}
\text { Void fraction }=100 \cdot\left(1-\frac{\rho_{\text {foam }}}{\rho_{\text {polymer }}}\right) & \text { Equation (1) } \\
\text { Cell Density }=\left(\frac{n}{A}\right)^{3 / 2} \cdot \frac{\rho_{\text {polymer }}}{\rho_{\text {foam }}} & \text { Equation (2) }
\end{array}
$$

In these equations, $\mathrm{n}$ is the number of cells and $\mathrm{A}$ is the area of image. $\rho_{\text {foam }}$ and $\rho_{\text {polymer }}$ is the density of the foam and unfoamed polymer.

\section{Rheological Properties}

The rheological behavior of the HIPS and HIPS/GPPS blends were measured with two methods: an oscillatory rheometer (Anton Paar, Rheo Compass.), and the melt flow index.Circular samples were hot pressed and prepared with a diameter of $25 \mathrm{~mm}$ and a gap size of $1 \mathrm{~mm}$ for rheological measurements.

\section{Results and Discussions}

\section{Polybutylene (PB) size determination in PS matrix}

Figure 2 compares the PB orientations of neat HIPS samples before and after extrusion process. It is seen that, PB orientations are similar in both situations. The diameters of PBs are as large as $20 \mu \mathrm{m}$.

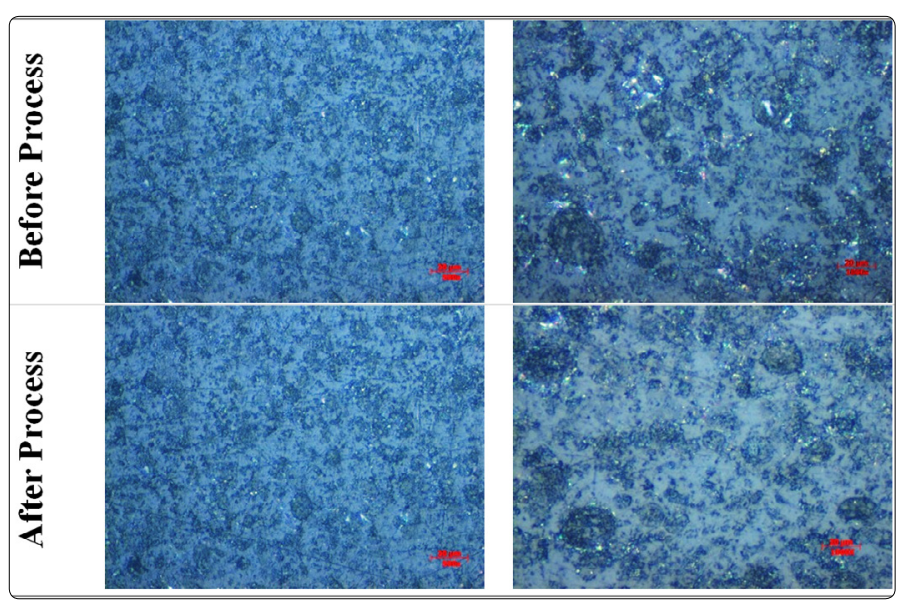

Figure 2. Optical microscope images of neat HIPS reflecting the PB droplet sizes before and after process. The scale bars are $20 \mu \mathrm{m}$ respectively.

\section{Melt behavior of the HIPS, GPPS and their blends}

Figure 3 shows the MFI results of HIPS, GPPS and their blends at $200{ }^{\circ} \mathrm{C}$ and $5 \mathrm{~kg}$. It is seen that, melt flow index values of HIPS, GPPS and their blends are very similar. This shows that; HIPS, GPPS and their blends have similar melt properties. GPPS has the highest MFI value $(4,5)$, while HIPS has 3,5 and increasing the content of GPPS increases the MFI of blends.

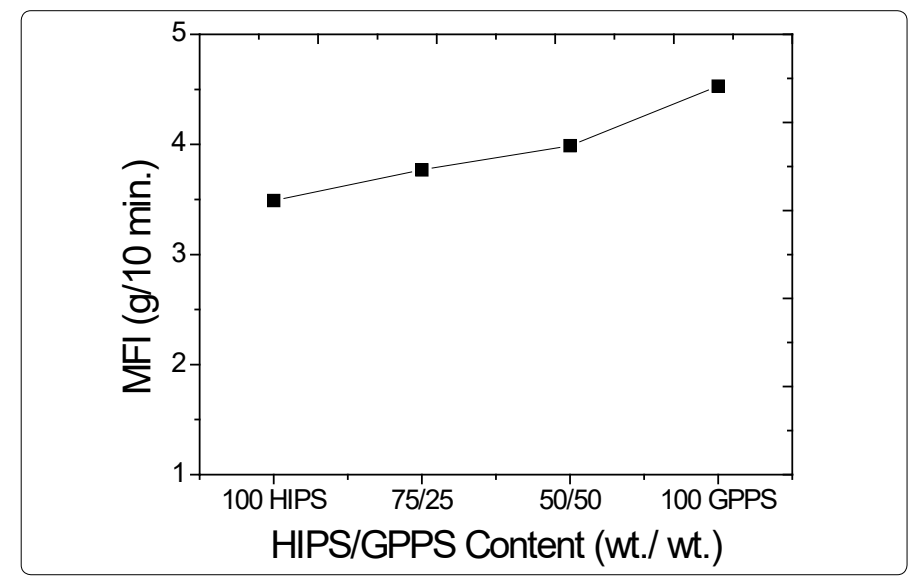

Figure 3. MFI results of HIPS, GPPS and their blends

Figure 4 also compares the frequency sweep short amplitude oscillation shearing (SAOS) behavior of the noted samples. As seen the complex shear viscosities and the moduli of HIPS and their blends with GPPS are pretty similar within the while frequency range. Therefore, the melt properties of HIPS, GPPS and their blends will have a similar effect on the corresponding foaming behavior of the samples. The very slight decrease of the viscosity and moduli of the HIPS blends with GPPS is due to the slightly higher MFI of GPPS compared to that of HIPS.

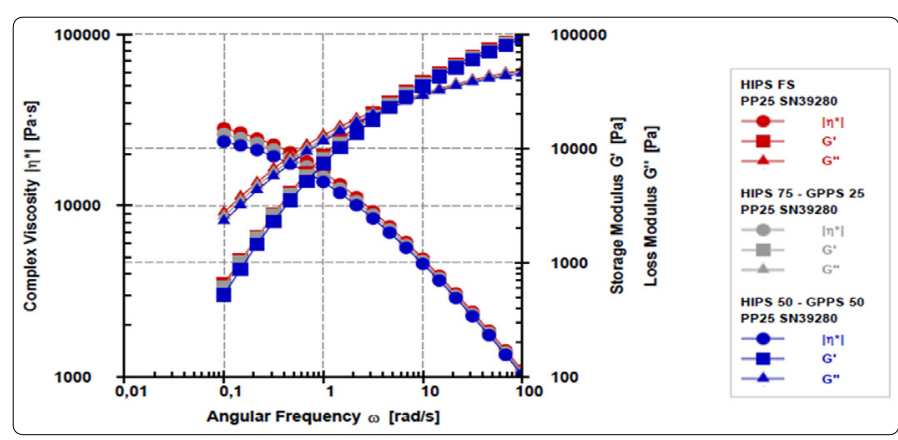

Figure 4. Complex shear viscosity of HIPS and their blends with GPPS at $200^{\circ} \mathrm{C}$

\section{Effect of Die Temperature}

Figure 5 shows the effect of die temperature on void fraction and cell density values of the foamed samples as well as on the die pressure variations when using both CBAs. In foamed samples with CBA 1, the highest void fraction ( 22\%) was obtained at the die temperature of $150^{\circ}$ which also possessed the highest cell density $\left(\sim 6 \times 10^{5} \mathrm{cell} / \mathrm{s} / \mathrm{cm}^{3}\right)$. This might be because the melt strength of polymer was proper enough for better cell nucleation and expansion at $150^{\circ}$ die temperature. As expected, the decrease in die temperature increased the die pressure. When using CBA 2 however, in foamed samples, despite the increased die pressure with the 
decrease in die temperature, the void fraction and cell density decreased with the decrease in die temperature.This could have been due to lack of solubility of CBA in melt at lower temperature as well as too high a stiff polymer melt for expansion at lower die temperatures. Figure 6 shows the SEM images of how various die temperatures influenced the cell morphology of the foamed HIPS with different CBAs.
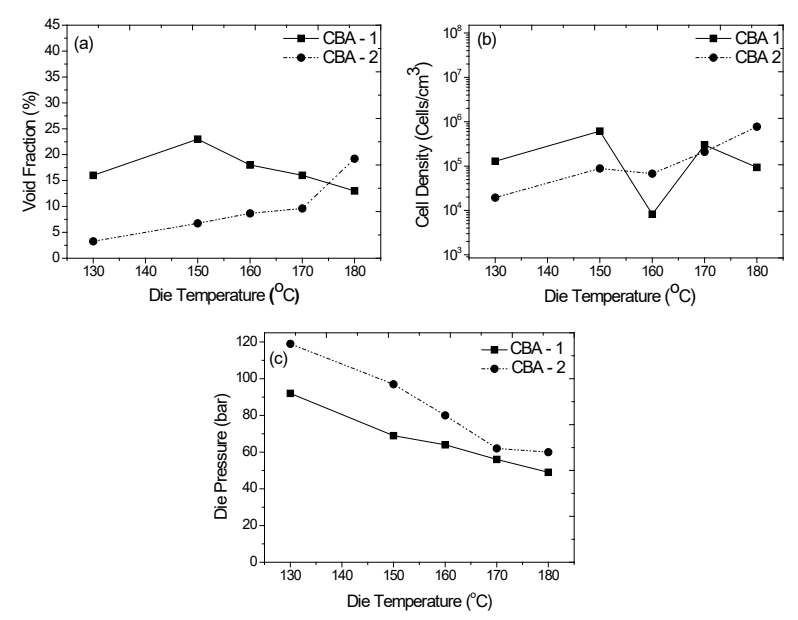

Figure 5. Effect of (a)die temperature on void fraction and (b)cell density of HIPS foams using 3 wt\% CBA (RPM 150), and on (c) die pressure variations

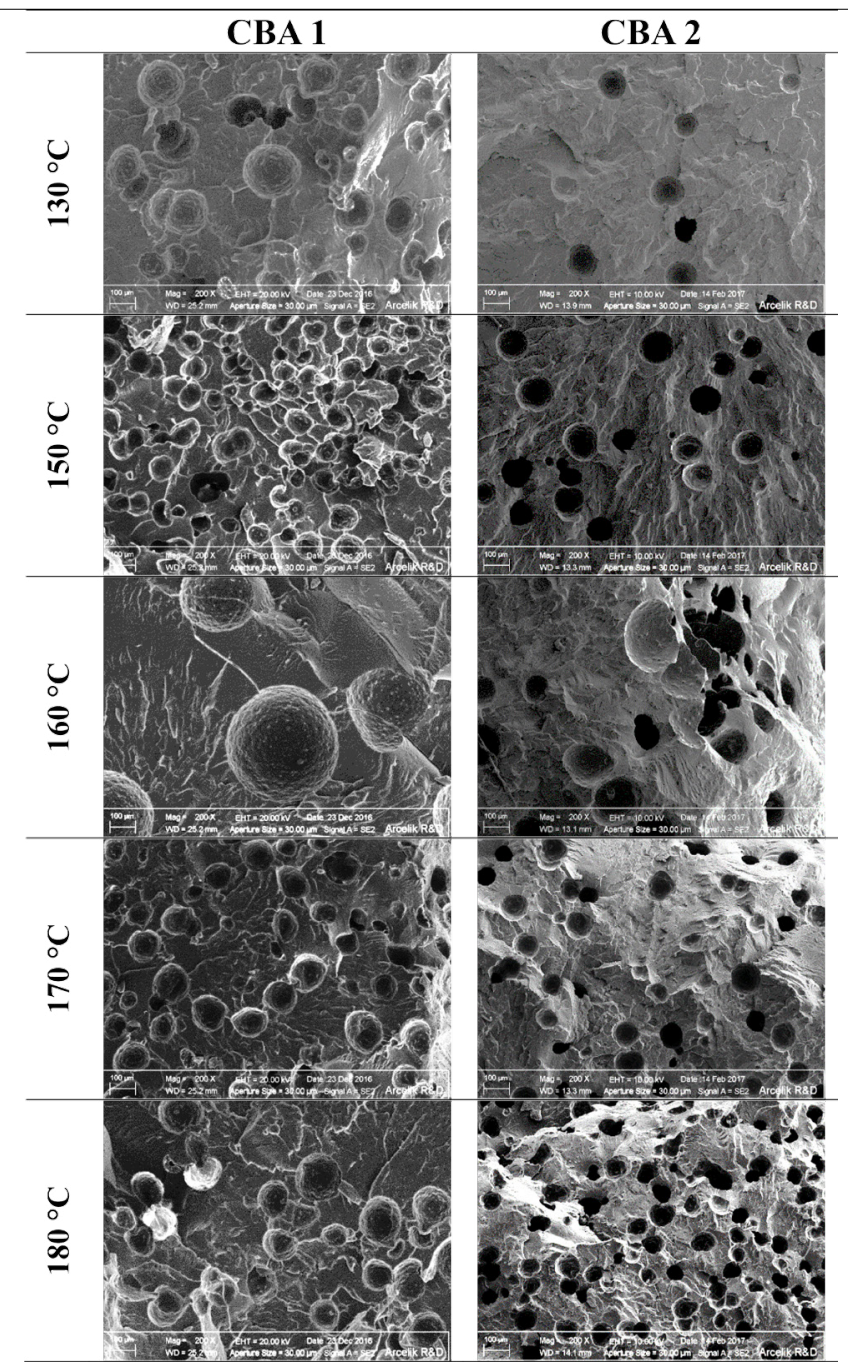

Figure 6. SEM images of the HIPS foamed samples at various die temperatures with CBA 1 and CBA 2

\section{Effect of CBA content}

Figure 7 shows the effect of CBA content on the void fraction and cell density values of the foamed samples. It is shown that increasing the CBA content from 1 to 5 wt. \% increased the void fraction and cell density in samples foamed with both CBA 1 and CBA 2. The highest void fraction ( 32\%) and the highest cell density $\left(\sim 2 \times 10^{7}\right.$ cells $\left./ \mathrm{cm}^{3}\right)$ were obtained for samples foamed with $5 \%$ wt. of CBA 1 . On the other hand, the highest void fraction $(\sim 21 \%)$ and the highest cell density $\left(\sim 8 \times 10^{5} \mathrm{cells} / \mathrm{cm}^{3}\right)$ were obtained for samples foamed with 5 $\%$ wt. of CBA 2. It should be noted that the cell density increased with increasing the CBA content from 1 to $5 \%$ wt due to the increase of the internal system pressure. Figure 8 shows the SEM images of how increasing CBA content influenced the cell morphology of the foamed HIPS with different CBAs.
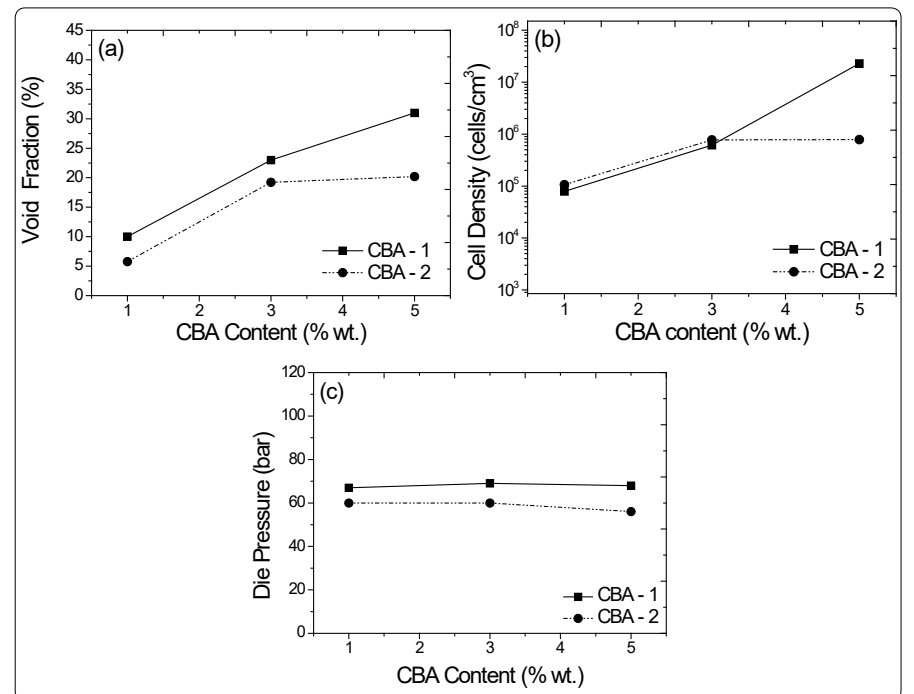

Figure 7. Effect of CBA content on (a) void fraction and (b) cell density of HIPS foams at optimized die temperature of $150^{\circ} \mathrm{C}$ and $180^{\circ} \mathrm{C}$, for CBA 1 and CBA 2, respectively (RPM 150)

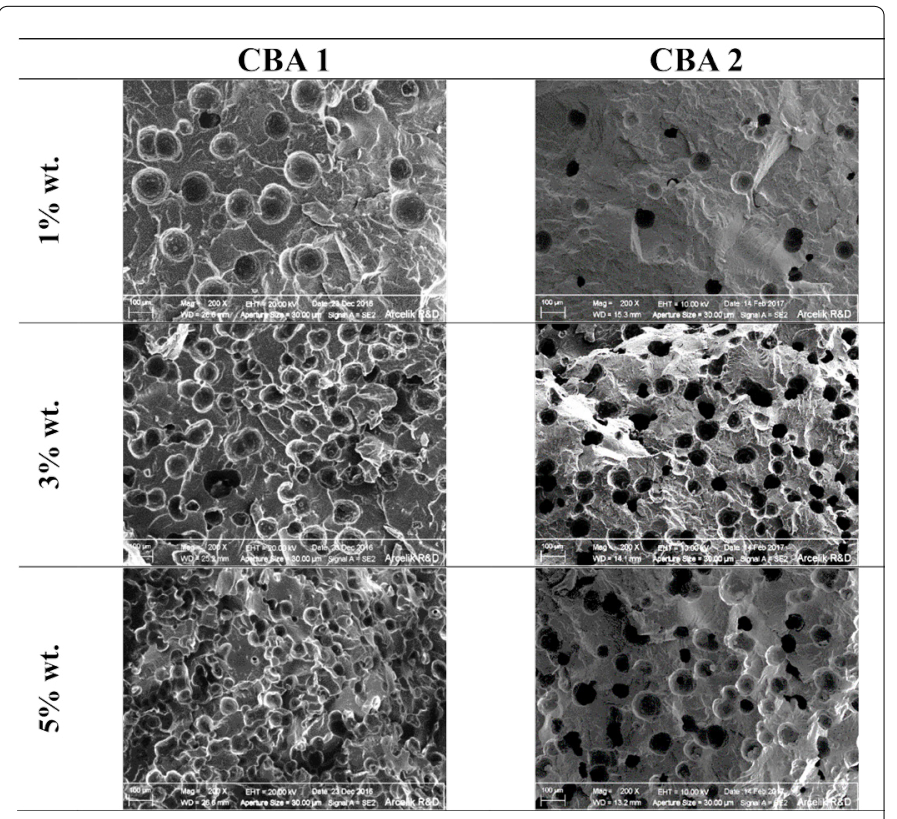

Figure 8. SEM images of the HIPS foamed samples with various CBA contents for CBA 1 and CBA 2 


\section{Effect of RPM}

Figure 9 shows the effect of screw RPM variations on the void fraction and cell density of the foamed samples. As the RPM decreased from around 250 to 100 , the die pressure and consequently the void fraction of the foamed samples increased and the maximum void fraction was achieved $\sim 30$ $\%$ for samples blown with both CBAs. On the other hand, the highest cell densities were obtained at 150 RPM and at 100 RPM for samples foamed with CBA $1\left(\sim 2 \times 10^{7}\right.$ cells $\left./ \mathrm{cm}^{3}\right)$ and CBA 2( 10 $10^{6}$ cells $\left./ \mathrm{cm}^{3}\right)$, respectively. The cell density and void fraction increase at lower RPMs were likely due to the better mixing of polymer melt and CBA due to the increased viscosity of polymer melt at lower RPM (lower frequencies as Figure 4 shows) and higher residual time, while the die pressures showed the highest values for both CBAs. Figure 10also shows the SEM images of how various RPM values influenced the cell morphology of the samples foamed with different CBAs.
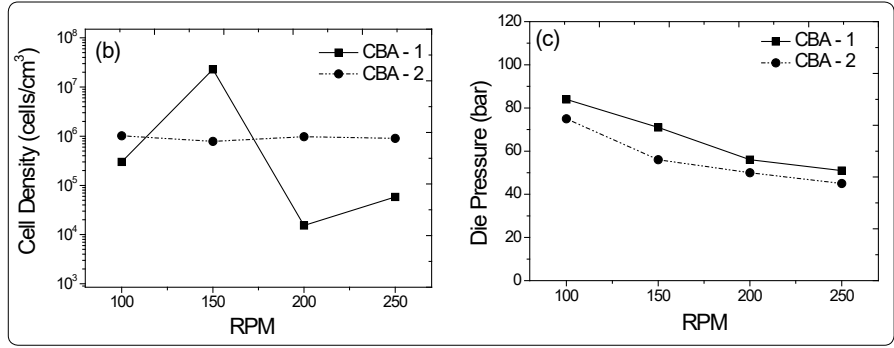

Figure 9. Effect of RPM on (a) void fraction and (b) cell density of HIPS foams at optimized die temperature of $150^{\circ} \mathrm{C}$ and $180^{\circ} \mathrm{C}$, for CBA 1 and CBA 2, respectively

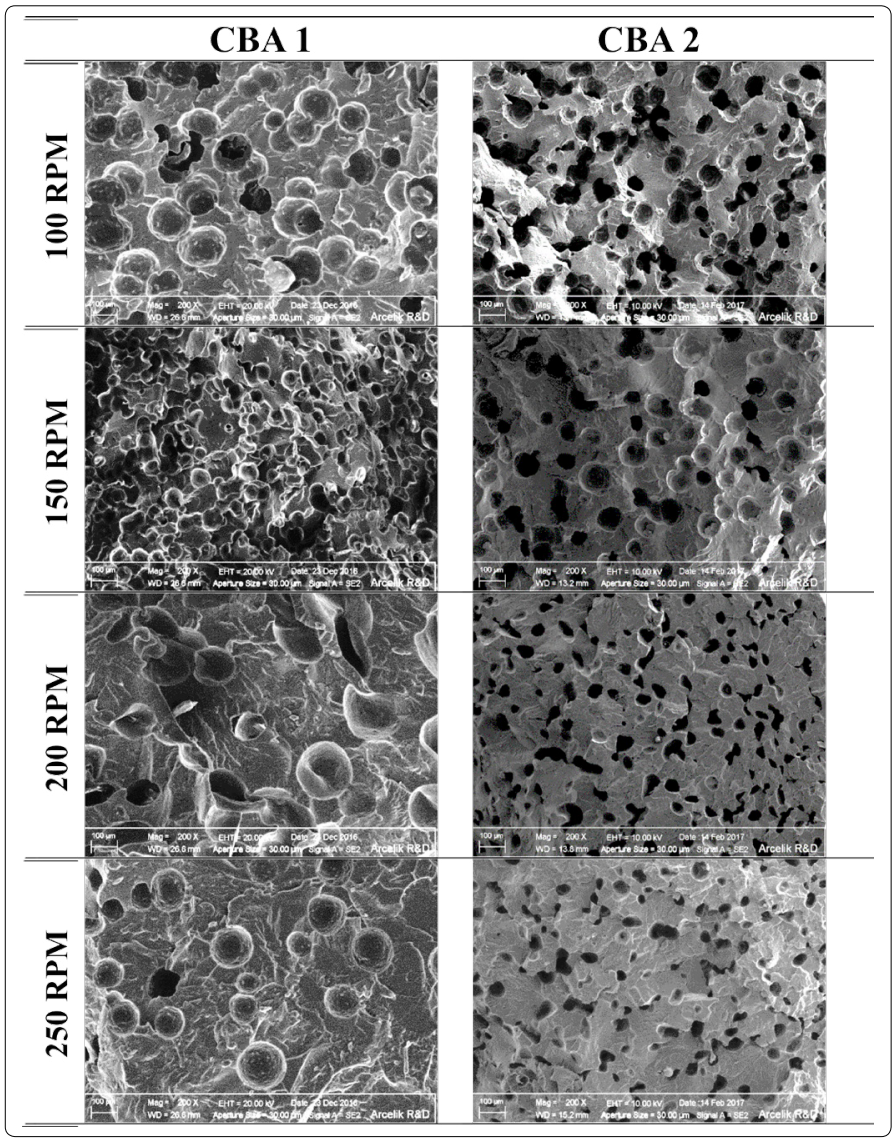

Figure 10. SEM images of the HIPS foams at different screw RPMs for samples foamed with two CBAs

\section{Effect of GPPS}

Figure 11 shows how the blending HIPS with GPPS could affect the void fraction and cell density of the foamed samples. The increase in GPPS content increased the cell densities of HIPS/GPPS blends to around $10^{6}$ cells $/ \mathrm{cm}^{3}$ with more of open celled structure. The SEM images of the blend samples (Figure 12) also confirms how the increase in GPPS increases the void fraction and cell density with more rigid but open-cell structure.
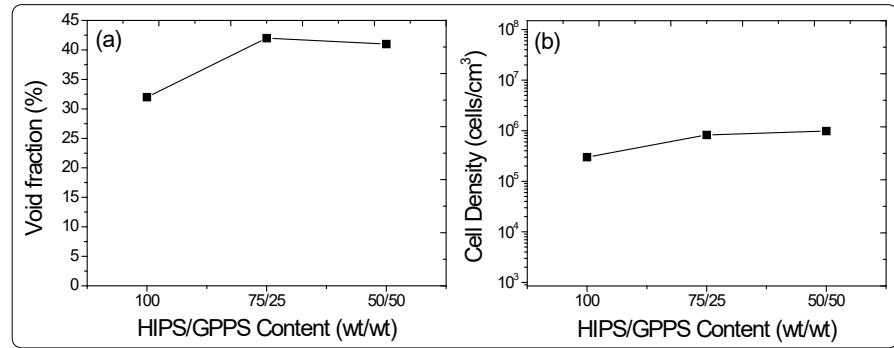

Figure 11. Effect of GPPS content on (a) void fraction and (b) cell density using CBA1 content of $5 \mathrm{wt} \%$ at die temperature of $150^{\circ} \mathrm{C}$ (RPM 100)

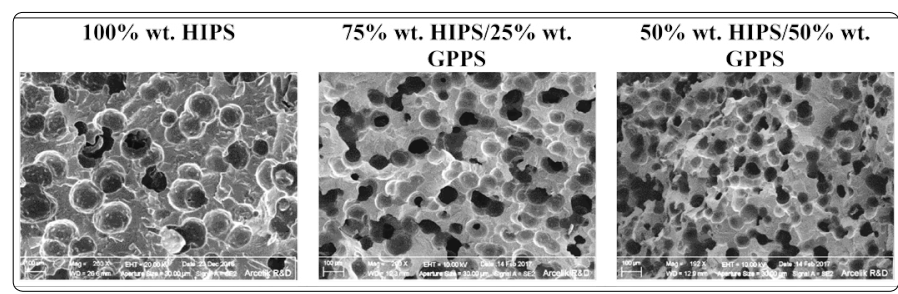

Figure 12. SEM images of the HIPS blend foams using CBA-1 content of $5 \mathrm{wt} \%$ at die temperature of $150^{\circ} \mathrm{C}$

\section{Effect of inorganic fillers}

Figure 13 also shows the effect of various inorganic fillers as cell nucleating agents on void fraction and cell density variations of the HIPS foamed samples. Increasing the inorganic filler content from 1 to $3 \mathrm{wt} \%$, increased the cell density for all fillers. Among these fillers, the highest cell density $\left(\sim 2 \times 10^{6}\right.$ cells $\left./ \mathrm{cm}^{3}\right)$ was obtained in composites with 3 wt \% of talc. Figure 14 also shows the SEM images of the foamed HIPS composites and how various fillers influenced the cell morphology. The void fraction decreased with increasing the inorganic filler content from 1 to $3 \%$ wt most probably due to the increased rigidity of the foamed samples.
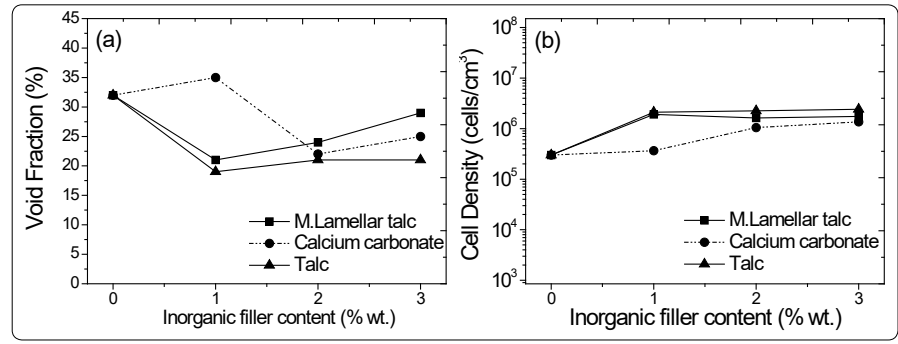

Figure 13. Effect of various inorganic fillers on (a) void fraction and (b) cell density of the HIPS composite foams using CBA1 content of $5 \mathrm{wt} \%$ at die temperature of $150^{\circ} \mathrm{C}$ (RPM 100) 


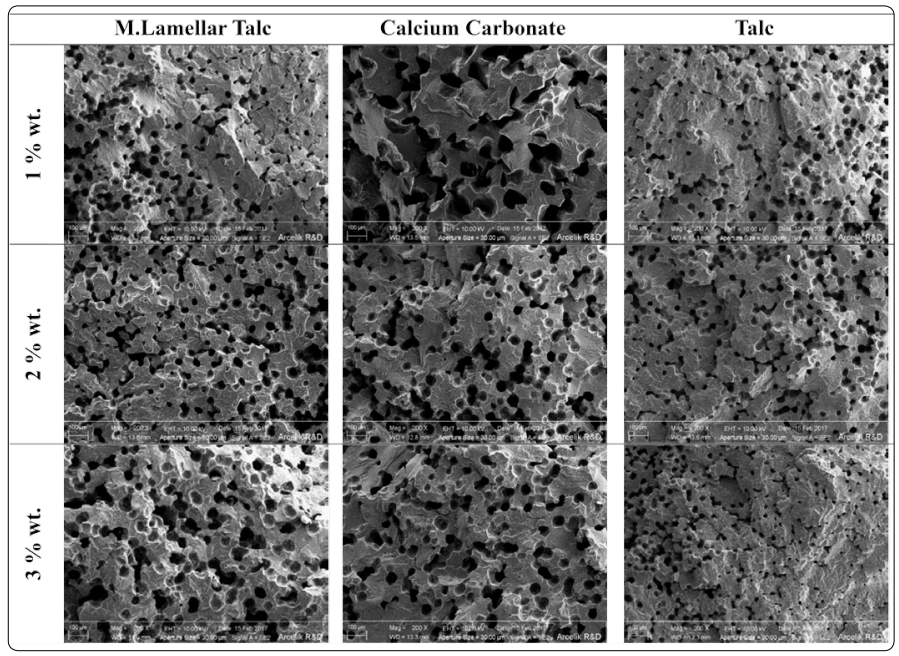

Figure 14. SEM images of the HIPS composite foams using CBA1 content of $5 \mathrm{wt} \%$ at die temperature of $150^{\circ} \mathrm{C}$

\section{Conclusion}

In this study, the extrusion foaming of HIPS through a twin-screw extruder with two different chemical blowing agents was studied and the effects of die temperature profile and screw speed (RPM); chemical blowing agent type and content; various inorganic fillers (i.e., micro lamellar talc, talc, and calcium carbonate) at three different contents (i.e., 1, 2, and $3 \mathrm{wt} \%$ ) and the foaming behavior of HIPS/GPPS blends at the blending ratios (wt\%/wt\%) of 75/25 and $50 / 50$ were studied. According to results; when the CBA content was maximum (5 wt\%) and the screw RPM was minimum (100), the cell density and the void fraction of the foamed HIPS increased. The increase in GPPS and inorganic filler contents increased the cell density and void fraction of HIPS foams while the type of inorganic fillers didn't reveal much differences from each other in the foaming results.

\section{References}

1. Lee ST, Park CB, Ramesh NS. Polymeric Foams: Science and Technology, Taylor \& Francis, Florida, 2006.

2. Gibson L, Ashby MF.Cellular Solids: Structure \& Properties. Pergamon Press, Oxford 1988.

3. Naguib HE, Park CB, Reichelt N. Fundamental Foaming Mechanisms GoverningVolume Expansion of Extruded PP Foams. J.of App.Polym Sci. 2004; 91(4): 2661-2668. doi: 10.1002/app.13448

4. Lee JWS, Wang K, Park CB. Challenge to Manufacture of Low-Density Microcellular Polycarbonate Foams Using CO2. Ind. Eng. Chem. Res. 2004; 44(1): 92-99. doi: 10.1021/ie0400402

5. Xu X, Xu D, Chen W, Pop-I liev R, Park CB, et al. Effects of the Die Geometry on Cell Nucleation of PS Foams Blown with $\mathrm{CO}_{2}$. SPE Topical Conference, Montreal 2001.

6. $\mathrm{Xu} D$, Park $C B$, Fenton RG. Strategies for the Manufacture of LowDensity, Fine-Celled PBS Sheet Foams Blown with $\mathrm{CO}_{2}$ Using an Annular Die. Society of Plastics Engineers, Annual Technical Conference - ANTEC, Boston, Massachusetts, 2005.

7. $\mathrm{Xu} \mathrm{D}$, Park $C B$, Fenton RG. Effects of the Convergent-Filamentary Die Geometry on Volume Expansion of PS Foams Blown with $\mathrm{CO}_{2} .7^{\text {th }}$ Blowing Agents and Foaming Processes, Stuttgart, Germany.(2005); 29(3): 143-162.

8. Wang J, Park CB. Pressure Profile in Annular Die Using $\mathrm{PP} / \mathrm{CO}_{2}$ Solution Viscosity, Society of Plastics Engineers, Annual Technical ConferenceANTEC, Charlotte, North Carolina, 2006.
9. Lee PC, Kaewmesri W, Wang J, Park CB, Pumchusak J, et al. Effect of Die Geometry on Foaming Behaviors of High-Melt-Strength Polypropylene with $\mathrm{CO}_{2}$. Society of Plastics Engineers, Annual Technical Conference -ANTEC, Cincinnati, Ohio, 2008; 109(5): 3122-3132. doi: 10.1002/app.28204

10. Wang J, Park CB, James DF. Effect of Die Land Length on Die Pressure During Foam Extrusion-Part I Experimental Observations, Society of Plastics Engineers, Annual Technical Conference-ANTEC, Cincinnati, Ohio, 2007.

11. Mark LH, Xu M, Park CB. Melt Fracture Behavior of PLA Foamed Using Different Die Entry Angles, Society of Plastics Engineers, Annual Technical Conference-ANTEC, Orlando, Florida, 2012.

12. Park CB, Suh NP. Extrusion of Microcellular Polymers Using a Rapid Pressure Drop Device, Society of Plastics Engineers, Annual Technical Conference-ANTEC, New Orleans, 1993

13. Guo $Q$, Wang J, Park $C B$, Ohshima M. Design of a Foaming Simulation System with a High Pressure Drop Rate, Society of Plastics Engineers, Annual Technical Conference -ANTEC, Chicago, Illinois. 2004.

14. Leung SN, Park CB. Effects of Gas Content and Pressure Drop Rate on Foaming, Annual Technical Conference-ANTEC, Charlotte, North Carolina. 2006.

15. Leung SN, Wong A, Park CB. Pressure Drop Threshold for Nucleation of $\mathrm{PS} / \mathrm{CO}_{2}$ Foaming, Society of Plastics Engineers, Annual Technical Conference -ANTEC, Cincinnati, Ohio, 2007.

16. Park $C B$, Suh NP. Filamentary Extrusion of Microcellular Polymers Using a Rapid Decompressive Element. Polym. Eng. Sci. 1996; 36(1): 34-48. doi: 10.1002/pen.10382

17. Park CB, Baldwin DF, Suh NP. Effect of Pressure Drop Rate on Cell Nucleation in Continuous Processing of Microcellular Polymers. Polym. Eng. Sci. 1995; 35(5): 432-440. doi: 10.1002/pen.760350509

18. Han CD, Villazimar CA. Studies on Structural Foam Processing I. The Rheology of Foam Extrusion. Polym. Eng. Sci. 1978; 18(9): 687-698. doi: 10.1002/pen.760180904

19. Blyler LL Jr, Kwei TK. Flow Behavior of Polyethylene Melts Containing Dissolved Gases. J. Polym. Sci. 1971; 35(1): 165-176. doi: 10.1002/ polc. 5070350113

20. Nikolaeva NE, Sabsai OY, Malkin AY, Fridman ML. Rheological Characteristics of the Extrusion of Articles from Foamed Thermoplastics, Int.Polym. Sci. Technol. 12 ;1985: 51-53.

21. Fridman ML, Sabsai OY, Nikolaeva NE, Barshtein GR. Rheological Properties of Gas-Containing Thermoplastic Materials during Extrusion. J. Cell. Plast. 1989; 25(6): 574-595. doi: 10.1177/0021955X8902500610

22. Kim KU, Kim BC, Hong SM, Park SK. Foam Processing with Rigid Polyvinylchloride. Int. Polym. Proc. 1989; 4(4): 225-231. doi: $10.3139 / 217.890225$

23. Kim BC, Kim KU, Hong SI. Foam Extrusion of Rigid PVC. III. The Rheological Properties of Unexpanded and Expandable Formulations. Polym. Soc.of Kor. 1986; 10: 324-331.

24. Mitrofanov AD, Panov YT, Kashcheeva NI. Effect of Chemical Blowing Agents on the Rheological Properties of Polystyrene. Int. Polym. Sci. Technol.1990;17: 26-28.

25. Sakino K, Ito K. Study on Extrusion Melt Flow of Foamed Polyvinylchloride. Reports Progr. Polym. Phys. 1982; 25: 195-198.

26. Dey SK, Jacob C, Biesenberger JA. Effect of Physical Blowing Agents on Crystallization Temperature of Polymer Melts. SPE Antec Tech.Pap. 1994; 40: $2197-2198$

27. Nofar M, Park CB. Poly (lactic acid) foaming. Prog Polym Sci. 2014; 39(10): 1721-1741. doi: 10.1016/j.progpolymsci.2014.04.001

28. Nofar M. Majithiya K, Kuboki T, Park CB. The foamability of low-meltstrength linear polypropylene with nanoclay and coupling agent. J. Cell. Plast. 2012; 48(3): 271-287. doi: 10.1177/0021955X12440271

29. Kesht kar M, Nofar M, Park CB, Carreau PJ. Extruded PLA/Clay Nanocomposite Foams Blown with Supercritical $\mathrm{CO}_{2}$. Polymer. 2014 55(16): 4077-4090. doi: 10.1016/j.polymer.2014.06.059 
30. Nofar M. Effects of nano-/micro-sized additives and the corresponding induced crystallinity on the extrusion foaming behavior of PLA using supercritical $\mathrm{CO}_{2}$. Mater Design. 2016; 101(5): 24-34. doi: 10.1016/j. matdes.2016.03.147

31. Pontiff TM. Factors Affecting Foam Cell Nucleation in Direct Gassed Foam Extrusion. Foamplas Conference, Mainz, 1997.

32. Colombo EA.Controlling the Properties of Extruded Polystyrene Foam Sheet. The MIT Press, Cambridge, 1979.

33. Jacobs WA, Collins FH. U.S. Patent 3,151,192.

34. Carlson Jr. U.S. Patent 2,797,443.

35. Kolosowski PA. U.S. Patent 5,424,016.

36. Pontiff TM, Rapp JP. U.S. Patent 5,059,376.

37. Miyamoto A, Akiyama H, Usuda Y. U.S. Patent 3,808,380.

38. Suh KW. U.S. Patent 4,916,166.

39. Nofar M, Park CB. Polylactide Foams: Fundamentals, Manufacturing and Applications. Elsevier, 2017.

40. Li G, Wang J, Park CB. Measurement of $\mathrm{N}_{2}$ Solubility in Polypropylene and Ethene/Octene Copolymer. SAE Tech. Pap. 2006; 4: 3-6.

41. Li YG, Hasan MM, Park CB. Determination of the Solubility of Blowing Agent in Polymer without Using any Equation of State, Society of Plastics Engineers, Annual Technical Conference -ANTEC, Chicago, Illinois, 2009.

42. Hasan MM, Li G, Park CB, Chen P. PVT and Solubility Behaviors of $\mathrm{CO}_{2} /$ $\mathrm{N}_{2}$ Blends in PS Melts, Foams. 2010, Seattle, Washington, 2010.

43. Sato Y, Fujiwara K, Takikawa T, Sumarno, Takishima S, Masuoka H,et al. Solubilities and diffusion coefficients of carbon dioxide and nitrogen in polypropylene, high-density polyethylene, and polystyrene under high pressures and temperatures. Fluid Phase Equilib. 1999; 162(1-2): 261276. doi: 10.1016/S0378-3812(99)00217-4

44. Gendron R. Thermoplastic foam processing: principles and development, CRC press, Florida, 2005.

45. Li G, Li H, Turng LS, Gong S, Zhang C, et al. Measurement of gas solubility and diffusivity in polylactide. Fluid Phase Equilib. 2006; 246(1-2): 158166. doi: 10.1016/j.fluid.2006.05.030
46. Mahmood SH. Phd Thesis, University of Toronto, Toronto, MA, 2012.

47. Hasan MM, Li YG, Li G, Park CB, Chen P. Determination of Solubilities of $\mathrm{CO}_{2}$ in Linear and Branched Polypropylene Using a Magnetic Suspension Balance and a PVT Apparatus. J. Chem. Eng. Data. 2010; 55(11); 48854895. doi: 10.1021/je100488v

48. Eaves D. Handbook of Polymer Foams, Rapra Technology, Shrewsbury, 2004.

49. Throne JL.Thermoplastic Foam Extrusion: an introduction, Hanser Gardner, Ohio, 2004.

50. Naguib HE, Park CB, Lee PC. Effect of Talc Content on the Volume Expansion Ratio of Extruded PP Foams. J. of Cell. Plas. 2003; 39(6): 499511. doi: $10.1177 / 0021955 \times 03039247$

51. Park CB, Suh NP. Filamentary Extrusion of Microcellular Polymers Using a Rapid Decompressive Element. Polym. Eng. Sci. 1996; 36(1): 34-48. doi: 10.1002/pen.10382

52. Park CB, Baldwin DF, Suh NP. Effect of the Pressure Drop Rate on CellNucleation in Continuous Processing of Microcellular Polymers. Polym. Eng. And Sci. 1995; 35(5): 432-440. doi: 10.1002/pen.760350509

53. Park CB, Behravesh AH, Venter RD. Extrusion of Low Density Microcellular HIPS Foams Using $\mathrm{CO}_{2}$. Polym. Eng. Sci. 1998; 38(11):1812-1823. doi: 10.1002/pen. 10351

54. Park CB. PhD Thesis, Massachusetts Institute of Technology, Cambridge, MA, 1993.

55. Park CB, Baldwin DF, Suh NP. Effect of the pressure drop rate on cell nucleation in continuous processing of microcellular polymers. Polym. Eng. and Sci.1995 ; 35(5) :432-440. doi: 10.1002/pen.760350509

56. Behravesh $A H$, Park CB, Pan M, Venter RD. Effective Suppression of Cell Coalescence During Shaping in the Extrusion of Microcellular HIPS Foams. 212 $2^{\text {th }}$ National ACS Meeting, Orlando, 1996.

57. Shimbo M, Nishida K, Nishikawa S, Sueda T, Eriguiti M,et al. Porous, Cellular and Microcellular Materials. ASME, New York, 1998. 